\title{
Variations of Proline-Rich Kinase Pyk2 Expression Correlate with Prostate Cancer Progression
}

\author{
Rosita Stanzione, Antonietta Picascia, Paolo Chieffi, Ciro Imbimbo, \\ Alessandro Palmieri, Vincenzo Mirone, Stefania Staibano, Renato Franco, \\ Gaetano De Rosa, Joseph Schlessinger, and Donatella Tramontano
}

\begin{abstract}
Dipartimento di Biologia e Patologia Molecolare e Cellulare "Luigi Califano" and Centro di Endocrinologia ed Oncologia Sperimentale del CNR "Gaetano Salvatore" (RS, AP, PC), Clinica Urologica (Cl, AP, VM), Dipartimento di Scienze Biomorfologiche e Funzionali, Sezione di Patologia (SS, RF, GDR), Università degli Studi di Napoli "Federico II" Naples, and Facoltà di Scienze (DT), Università del Sannio, Benevento, and Dipartimento di Medicina Sperimentale e Clinica "Gaetano Salvatore" (DT), Università di Catanzaro "Magna Græcia," Catanzaro, Italy; and Department of Pharmacology (JS), New York University Medical Center, New York City, New York
\end{abstract}

SUMMARY: Proline-rich kinase 2 (Pyk2), also known as CAK $\beta$ (cell adhesion kinase $\beta$ ), is a cytoplasmic tyrosine kinase that is structurally related to focal adhesion kinase. Pyk2 is expressed in different cell types including brain cells, fibroblasts, platelets, and other hemopoietic cells. Pyk2 is rapidly tyrosine phosphorylated in response to diverse extracellular signals acting via different post receptor pathways. We have investigated whether this protein kinase is functionally expressed in normal and neoplastic prostate tissues. In this study, we demonstrate that Pyk2 is expressed only in normal epithelial prostate tissue and in benign prostatic hyperplasia, whereas its expression progressively declines with an increasing grade of malignancy of prostate cancer. (Lab Invest 2001, 81:51-59).

\begin{abstract}
$P$ rostate cancer is the most common cancer in Western men and the second leading cause of death after cardiovascular diseases. Large efforts to find an effective therapy for prostate cancer have been made. With the appearance of androgen-insensitive cells within the tumor, most of the benefits obtained by hormonal therapy vanish. In fact, prostate cancer begins as an androgen-dependent tumor that undergoes clinical regression in response to pharmacologic or surgical strategies to reduce testosterone concentration. Despite these treatments, in most cases the cancer regrows as an androgen-independent or hormone-independent tumor. There are several hypotheses about the molecular mechanisms of prostate tumor progression; attention is focused on the possibility that the androgen receptor itself mediates the androgen-independent progression (Craft et al, 1999; Talpin et al, 1995; Visakorpi et al, 1995).

Prostate cell differentiation and growth are under the control of a number of hormones and growth factors whose interrelationships are not fully understood (Culing et al, 1995, 1996). The role of testosterone in regulating the growth and differentiation of
\end{abstract}

Received August 7, 2000.

These authors contributed equally to this report: RS, AP. This work was supported by grants from the Associazione Italiana Ricerca sul Cancro and from MURST/CNR "Biotecnologia."

Address reprint requests to: Dr. Donatella Tramontano, Dipartimento Biologia e Patologia Molecolare, e Cellulare "Luigi Califano,"Via Pansini, 580131 Naples, Italy.E-mail: Tramontano@unisannio.it prostate cells is still unclear. Although testosterone is an essential factor for prostate gland development, it is not clear whether testosterone is a direct mitogen for prostate acinar cells (Griffiths et al, 1997; Lee et al, 1997; Lin et al, 1998; Ruijter et al, 1999).

The complex relationship between the stromal and endocrine components of the prostate gland suggests a role for growth factors in the regulation of the prostate. Insulin or epidermal growth factor (possibly produced locally by the stromal component of the prostate) together with testosterone may contribute to the regulation of prostate cell proliferation, acting through a paracrine stromal/acinar loop (Berthon et al, 1997; Culing et al, 1995, 1996; Griffiths et al, 1997; Russell et al, 1998; Sherwood et al, 1998; Udayakumar et al, 1999). Thus, it is important to understand how post receptor pathways, activated through different receptors, interact to control proliferation and differentiation of prostate cells. Because kinase activity, stimulated by diverse hormones and growth factors, plays a central role in the control of cell proliferation and differentiation, alterations of kinase activity might be important in the development of androgendependent or -independent prostate cancer (Robinson et al, 1996; Visakorpi, 1999).

Proline-rich kinase 2 (Pyk2), also known as CAK $\beta$ (cell adhesion kinase $\beta$ ) is a cytoplasmic tyrosine kinase that is related to focal adhesion kinase (Fak) (Dikic et al, 1998; Lev et al, 1995; Sasaki et al, 1995). Pyk2 is activated by increases in intracellular calcium concentrations and various extracellular signals, in- 
cluding inflammatory cytokines, TNF $\alpha$, UV irradiation, and changes in osmolarity. Pyk2 can function as an upstream mediator of the JNK (c-Jun N-terminal kinase) signaling pathway via an unknown mechanism (Tokiwa et al, 1996). Pyk2 can activate the Ras-MAPK (mitogen-activated protein kinase) signaling pathway by both direct and indirect recruitment of the adapter proteins Grb2 and Shc (Dikic et al, 1996). Thus, Pyk2 seems to be a key mediator of intracellular signaling, linking a variety of extracellular stimuli to the MAPK pathway, the JNK pathway, or both, depending on the context (Guo et al, 1998). Therefore, we investigated whether Pyk2 is expressed in the prostate and whether it plays a role in the regulation of prostate cell growth.

In this study we found that Pyk2 was expressed in normal human prostate cells of epithelial origin and not in the stromal component of the gland. Moreover, Pyk2 expression was inversely correlated with malignancy in the prostate, because its expression decreased with increasing malignancy of prostate cancers.

\section{Results}

\section{Pyk2 Is Activated in the Prostate Tissue}

To determine the presence of Pyk2 in human prostate tissue, $500 \mu \mathrm{g}$ samples of total lysate from normal or hyperplastic specimens were immunoprecipitated and immunoblotted with a Pyk2-specific antibody. Pyk2 immunoprecipitated from prostate samples migrated in the SDS gel as a doublet in which the major band had an apparent molecular weight of 106,000 kd and the minor band had an apparent molecular weight of 110,000 kd (Fig. 1b). Dikic et al (1998) demonstrated the presence of different Pyk2 isoforms in mouse tissues. In agreement with their results, a single band with the apparent molecular weight of $110,000 \mathrm{kd}$ was present in the PC12 cells that were used as a positive control. The same membrane was probed with antibodies against phosphotyrosine and, as shown in Figure 1a, Pyk2 seemed to be phosphorylated in all samples tested. This would indicate that Pyk2 is expressed in an active state in normal human prostate tissue. Pyk2 expression in the prostate was restricted

$$
\text { IP: anti Pyk2 }
$$

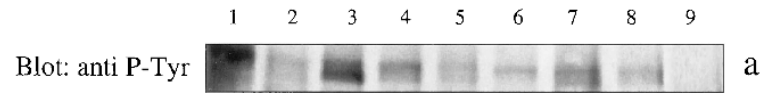

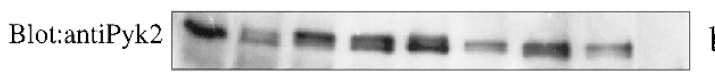

Figure 1.

The expression and activation of Pyk2 in human normal prostate tissues (lanes 2, 3, 4, 5, 6, 7, 8), in PC12 cells as a positive control (lane 1), and in a primary culture of fibroblasts derived from normal prostate tissue (lane 9). Total lysates $(500 \mu \mathrm{g})$ from normal specimens and PC12 cells were subjected to immunoprecipitation and immunoblot with antibodies to phosphotyrosine $(\mathrm{A})$ and to Pyk2 (B). to the epithelial portion of the gland, as demonstrated by the absence of immunoreactive material in the immunoprecipitate of primary culture fibroblasts derived from human prostate specimens (Fig. 1, lane 9).

\section{Detection of Pyk2 Expression in Normal Prostatic Gland, Benign Prostatic Hyperplasia, and Prostatic Cancer}

Immunohistochemistry was used to investigate whether the expression of Pyk2 correlated directly or inversely with the malignancy of the prostate. Biochemical analysis of tumor homogenates is problematic because of the possibility of the presence of normal prostate tissue in the specimens from cancer patients. This inadvertent combination of normal and cancerous tissues could make the interpretation of the results difficult, if not impossible (Gioeli et al, 1999). Immunohistochemical analysis allowed us to precisely detect the presence of Pyk2-specific immunoreactivity at the level of the epithelial and the stromal component of normal, hyperplastic, or neoplastic prostate samples.

Forty-three prostate tumor specimens were analyzed for the presence of Pyk2. The immunoreactivity was graded as I ( $0 \%$ to $5 \%$ of cells were immunoreactive), II (5\% to $25 \%$ of cells were immunoreactive), or III (more than $25 \%$ of cells were immunoreactive). Cytoplasmic Pyk2 immunoreactivity was found in nearly all of the prostatic normal tissues (Fig. 2a). The intensity of immunoreactivity ranged from mild (grade II) to intense (grade III), irrespective of the topographic origin (peripheral, central, posterior) of the sample. Pyk2-specific immunoreactivity was confined to the cytoplasm of prostate epithelial cells; the stroma was always negative (Fig. 2b). Immunoreactivity was frequently stronger at the apical pole of the cell (Fig. 2b).

In areas of adenocarcinoma, the degree of immunoreactivity decreased progressively with rising cytologic grades of malignancy. In particular, the 10 cases of well-differentiated cancer had diffuse cytoplasmic immunoreactivities that were frequently less intense than the normal counterpart (graded as I to II) (Fig. 2c). A significant decrease of immunoreactivity (grade I, sometimes with discontinuous distribution patterns) was observed in 14 cases of intermediate grade adenocarcinomas. Moreover, a complete loss of immunoreactivity was observed in 19 cases of highgrade and anaplastic carcinomas (Fig. 2d).

Statistical analysis showed a significant inverse correlation between Pyk2 expression and tumor grade. Statistically significant differences $(p<0.01)$ were observed in the levels of Pyk2 expression between low grade and high grade prostate cancers and between medium grade tumors and high grade adenocarcinomas. However, no statistically significant difference $(p>0.05)$ was observed in the expression of Pyk2 between low grade and medium grade prostate cancers.

\section{Fak Expression in Normal and Prostate Cancer Tissues}

The expression of Fak and Pyk2 were compared in the same samples of normal and neoplastic prostate 


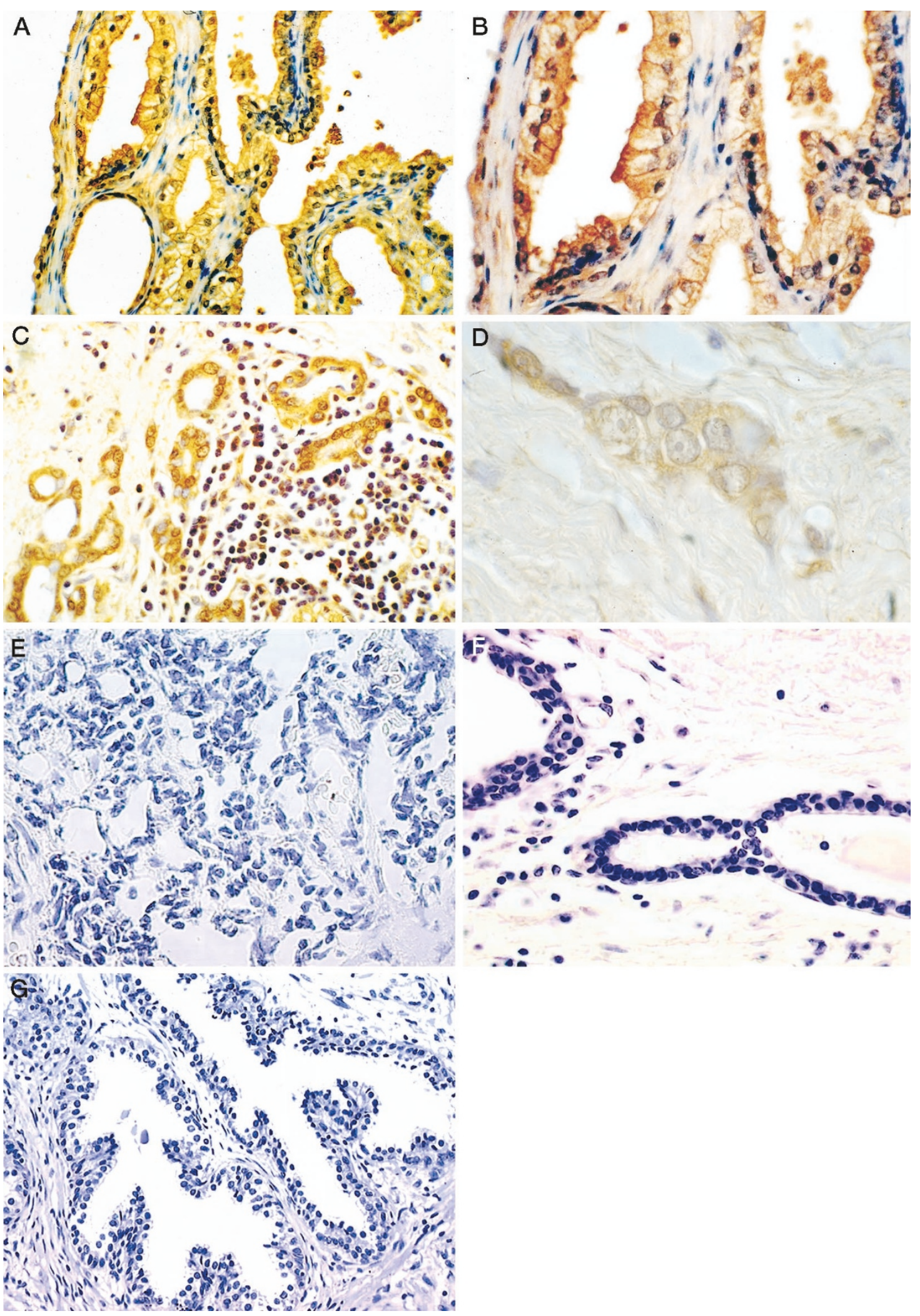

Figure 2.

(A) Intense cytoplasmic immunoreactivity for Pyk2 protein in both normal and hyperplastic prostatic epithelial cells. Original magnification, $\times 250$. (B) The same case at higher magnification showing the complete lack of Pyk2 immunoreactivity in the stromal component and the presence of signal reinforcement in the apical pole of prostate epithelial cells. Original magnification, $\times 400$. (C) Diffuse cytoplasmic immunoreactivity for Pyk2 protein in a case of low-grade prostatic adenocarcinoma. Original magnification, $\times 250$. (D) A case of intermediate-grade prostatic adenocarcinoma showing moderate cytoplasmic expression of Pyk2. Original magnification, $\times 400$. (E) A case of high-grade prostatic adenocarcinoma completely negative for Pyk2 protein. Original magnification, $\times 250$. (F) Negative control, normal prostate tissue treated with normal rabbit serum instead of the primary antibody. (G) Negative control, normal prostate tissue challenged with Pyk2 antibody and preadsorbed with an excess amount of cognate peptide $\left(10^{-6} \mathrm{M}\right)$. Original magnification, $\times 250$. 
cancer. Total lysates from normal prostate tissues and from PC3 cells were immunoprecipitated with antibodies against Pyk2 and Fak. Filters were blotted first with antibodies against Pyk2 or Fak, respectively, and then with phosphotyrosine antibodies. As shown in Figure 3 (upper panel), Pyk2 is highly expressed in an active state in the normal prostate with respect to Fak (Fig. 3, lower panel). Total lysates from tumor tissues were immunoprecipitated with antibodies to Fak or with an unrelated immunoglobulin and immunoblotted with Fak antibodies. As shown in Figure 4, a band with the appropriate molecular weight for Fak was present in the two cancer tissues and in the PC3 cells that were used as a positive control. No bands were observed when the lysates were immunoprecipitated with an unrelated IgG. To further characterize the expression of the two proteins in normal and neoplastic tissue, the same sections analyzed immunohistochemically with Pyk2 antibodies were immunoreacted with Fak antibodies. In all cases examined, strong immunoreactivity for Fak was present in high-grade adenocarcinomas (Fig. 5a). Fak immunoreactivity was decreased in low-grade carcinomas (Fig. 5b), and was almost completely absent in normal and hyperplastic prostate glands (Fig. 5c).
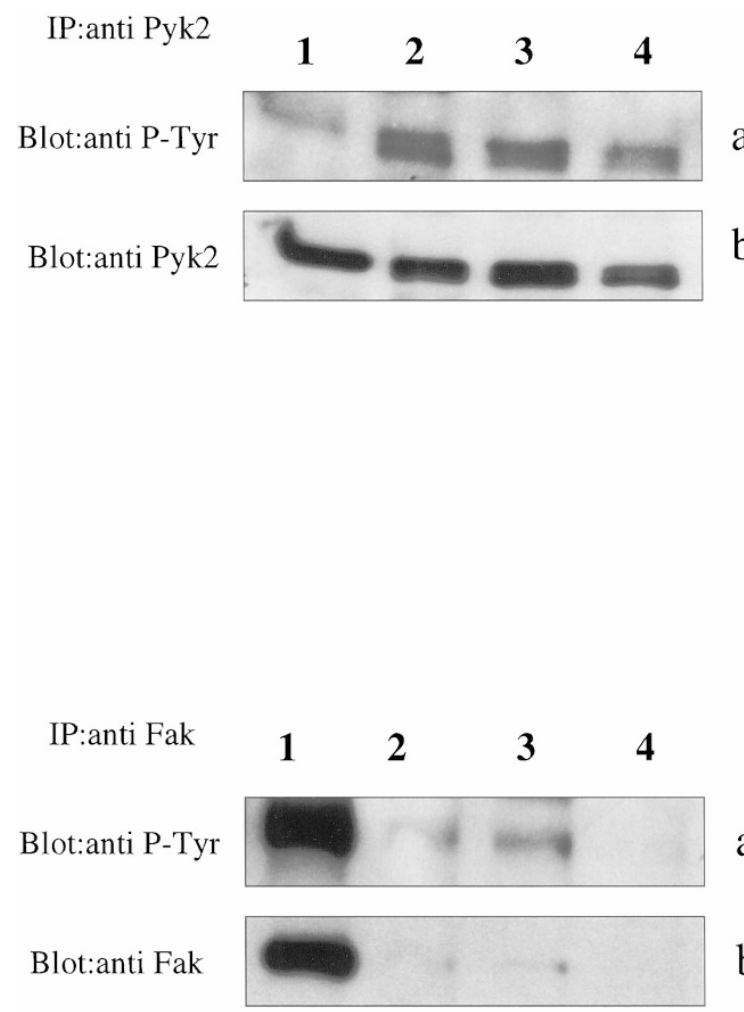

Figure 3.

Pyk2 and Fak expression and activation in human normal prostate tissues from different patients (lanes 2, 3, 4) and from PC3 cells maintained in serum-free medium for 24 hours as positive control (lane 1). Upper panel: $500 \mu \mathrm{g}$ of total lysate from normal specimens was subjected to immunoprecipitation with Pyk2 antibodies and immunoblot with specific phosphotyrosine antibodies (A) and with specific Pyk2 antibodies (B). Lower panel: the same lysates were subject to immunoprecipitation with Fak antibodies and immunoblot with specific phosphotyrosine antibodies $(A)$ and with specific Fak antibodies (B).

$$
\text { IP: anti Fak }
$$

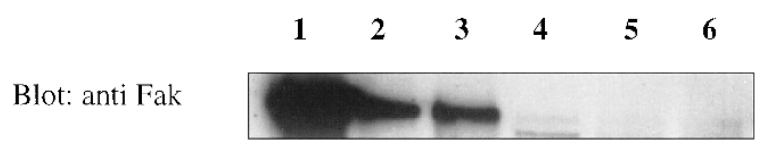

Figure 4.

The expression Fak in human cancer prostate tissues (lanes 2 and 3 ) and in PC3 cells as positive control (lane 1). Total lysate $(500 \mu \mathrm{g})$ from cancer specimens and from PC3 cells was subjected to immunoprecipitation and immunoblot with Fak antibodies. Lanes 4 to 6: the same samples were immunoprecipitated with an unrelated $\mathrm{Ig} G$ and immunoblotted with Fak antibodies.

Statistical analysis showed a significant correlation between Fak expression and the increase of tumor grade. Statistically significant differences were observed in the levels of Fak expression between high grade and low grade prostate cancers $(p<0.01)$ and between high grade tumors and medium grade adenocarcinomas $(p<0.05)$. No statistically significant difference $(p>0.05)$ was observed in Fak expression between medium grade and low-grade prostate cancers.

\section{Discussion}

We examined 43 prostate tumor specimens for the presence of Pyk2 protein. Our results demonstrate, for the first time, that Pyk2 is expressed in an activated state in normal prostate epithelium and is absent in the stroma. Additionally, the levels of Pyk2 progressively decreased in prostate tumors with increasing malignancy, and disappeared completely in high-grade and dedifferentiated anaplastic tumors.

A precise map of the signals and signal transduction pathways involved in the regulation of prostate cell growth and differentiation is not yet available. However, our results suggest that Pyk2 expression correlates with the state of differentiation of the prostate cells. Additionally, our results seem to indicate that Pyk2 expression correlates with androgen receptor expression in normal and pathologic prostate. In fact, both Pyk2 and steroid receptors are highly expressed in normal or benign prostatic hyperplasia, where they might cooperate in the regulation of proliferation and differentiation. When steroid receptor function is decreased, as in the case of adenocarcinomas, Pyk2 expression was also decreased. Finally, Pyk2 is totally absent in high-grade cancer, which is generally characterized by loss of steroid receptor activity.

Pyk2 could thus take part in the complex network of signal transduction pathways controlling both prostate proliferation and differentiation. This may possibly occur via the activation of MAPK and/or JNK pathways (Dikic et al, 1996; Lev et al, 1995). There may be interactions between steroid-activated signal transduction pathways and polypeptide growth factoractivated pathways, as demonstrated for estrogen receptors (Culing et al, 1995; Reinikainen et al, 1996). In the prostate, Pyk2 could be involved in the interac- 


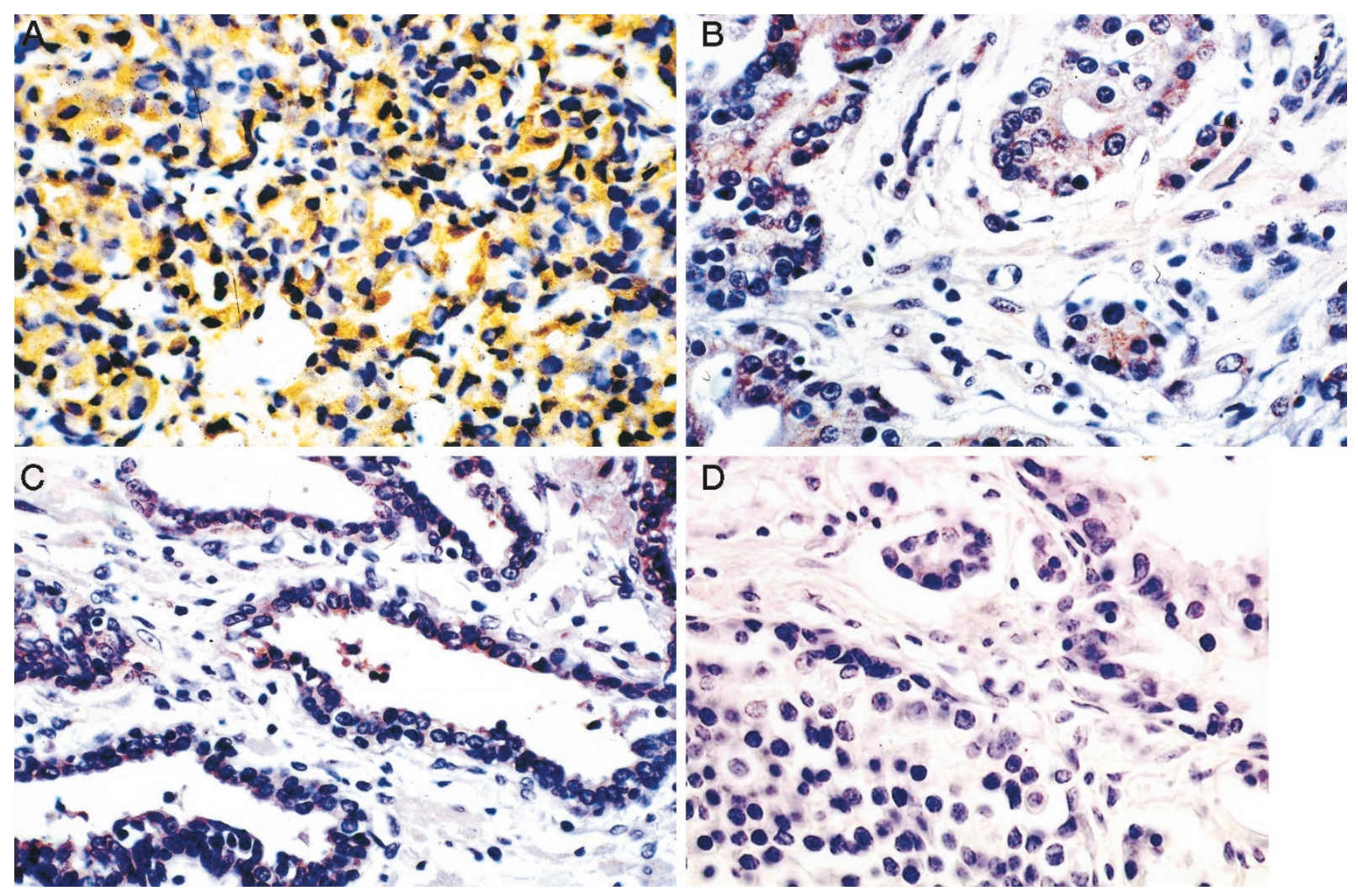

Figure 5.

(A) Diffuse cytoplasmic immunoreactivity for FAK protein in a case of prostatic adenocarcinoma with a moderate degree of differentiation. Original magnification, $\times 250$. (B) Very low cytoplasmic immunoreactivity for FAK protein in a case of low-grade prostatic adenocarcinoma. Original magnification, $\times 250$. (C) Absence of immunoreactivity for FAK protein in a case of normal/benign hyperplastic prostate. Original magnification, $\times 400$. (D) Negative control in a case of adenocarcinoma.

tions between signal transduction pathways activated via androgen receptors and growth factors, stress signals, or cytokine receptors (Dikic et al, 1998; Tokiwa et al, 1996). Preliminary observations in our laboratory indicate that the levels of Pyk2 expression are low in areas of acute prostatitis (data not shown), but very strong in adjacent areas of normal or hyperplastic gland. It is possible that chemokines, produced locally during the inflammation process and sustaining the prostatitis, regulate the expression of Pyk2 in the normal or hyperplastic part of the gland. (Balbay et al, 1999; Mazzucchelli et al, 1996; Moore et al, 1999; Veltri et al, 1999). This might represent a physiologic role of Pyk2 in the regulation of prostate acinar cells. In addition, in the prostate Pyk2 expression might be regulated by factors, such as stress signals, as it is in other systems.

The presence of Pyk2 in normal differentiated tissue and the progressive loss of Pyk2 expression in highgrade prostate adenocarcinomas suggest that Pyk2 is an onco-suppressor gene, at least in the prostate. Additionally, Pyk2 is localized in the p21.1 region of chromosome 8 (Inazawa et al, 1996), and interstitial deletions of the regions 8p21 and 8p12 to 8p23 or the loss of chromosome 8 are associated with prostate cancers (Kalapurakal et al, 1999; Konig et al, 1999; Van Alewijk et al, 1999). A direct correlation between loss of chromosome 8 and degree of malignancy in prostate tumors has not been shown; although loss of chromosome 8 is more frequent in prostate tumors with a Gleason score higher than 8, loss of chromosome 8 is also observed in tumors with Gleason scores lower than 8. Topographic comparative studies on normal and neoplastic tissue, correlating Pyk2 expression with specific markers of prostate differentiation (such as PSA and androgen receptors) may clarify many of the unresolved questions.

Because the imbalance between cell proliferation and cell apoptosis is believed to be a key factor in carcinogenesis, particular attention is given to the alteration of the apoptotic pathway in the progression from pre-neoplastic lesion to prostate cancer (Bruyninx et al, 2000; Xie et al, 2000). Despite large efforts and several candidate genes, there is not yet a definite correlation between mutation or alteration in the expression of genes involved in the apoptotic process with different stages of prostate cancer progression (Bostwick et al, 2000; Moul, 1999). However, current studies on the relation of Pyk2 expression to apoptosis assign Pyk2 a role in the pathway that induces apoptosis (Chauhan et al, 1999; Pandey et al, 1999a, 1999b; Susa 1999). Xiong and Parson (1997) report that the ectopic expression of Pyk2 causes apoptosis in several fibroblast and epithelial cell lines and that loss of Pyk2 can cause resistance to physiologic apoptosis. Additionally, Ueda et al (2000) report the identification of FIP-200 (Fak family kinase-interacting protein), which inhibits Pyk2 kinase activity via binding 
to the kinase domain of Pyk2. The formation of FIP 200-Pyk2 complexes inhibits Pyk2-triggered apoptosis in Rat 1 cells. Taken together, these data and our observations support a role of Pyk2 as an oncosuppressor gene.

Fak seems to be involved in the progression and invasion of various human cancers, including prostate tumors (Schaller et al, 1992; Zheng et al, 1998). An increase in the expression and activation of Fak was observed in metastatic prostate cancer and in highly tumorigenic PC3 cells. However, normal prostate, hyperplastic prostate, and localized cancer prostate tissues showed undetectable or low levels of both Fak mRNA and protein and an absence of Fak signaling complex (Felsch et al, 1999; Owens et al, 1995; Tremblay et al, 1996a, 1996b). However, the few reports present in the literature do not allow a direct correlation to be drawn between Pyk2 expression and cancer (Ganju et al, 1998a, 1998b; Hatch et al, 1998; Liu et al, 1997; Mukhopadhyay et al, 1998). The results presented here indicate a correlation between Pyk2 expression and cancer progression, because Pyk2 expression disappears in prostate neoplasia with the increase of the grade of malignancy. Our data on the differential expression of Pyk2 and Fak in the prostate sheds new light on the functional relationship between the two genes (Sieg et al, 1998). Examining the extreme cases, in normal prostate cells, Pyk2 is present in an active state whereas Fak is absent; in anaplastic adenocarcinomas, Fak is highly expressed whereas Pyk2 is absent. However, the most interesting results come from the observation that in intermediate grade cancers there are areas where Fak is present and Pyk2 is absent. Immunohistochemistry allowed us to hypothesize an incompatibility between Pyk2 and Fak, because it was possible to recognize that the same areas within a certain sample were immunoreactive for only one of the two proteins, in an all or nothing phenomenon. The transition from a Pyk2-expressing prostate cell to a Fak-expressing prostate cell could be an essential step in the transition from a normal differentiated to neoplastic, poorly differentiated prostate cell.

The balance between Fak and Pyk2 expression could be used as a sensitive prognostic index in prostate cancer. Early screening for the presence of Fakimmunoreactive areas within Pyk2-immunoreactive prostate tumors could give indications on the possible evolution of the disease, whereas the absence of Pyk2 immunoreactivity may indicate a poor prognosis.

\section{Methods}

\section{Samples from Human Biopsies}

Human prostates from patients with prostate cancer were obtained after radical prostatectomy. Tissue samples were frozen in dry ice immediately after removal and kept at $-135^{\circ} \mathrm{C}$ until use.

Forty-three cases of resected prostatic cancer were selected. There were 19 high-grade cases with combined Gleason scores of 7 to 9, 14 intermediate-grade cases with Gleason scores of 5 to 6 , and 10 lowgrade, well-differentiated cases with Gleason scores of 2 to 4 (Gleason and Mellinger, 1974; Gleason, 1977; Humphrey et al, 1993). Before resection, all patients were treated with complete androgen blockade according to international standard therapeutic protocols (Fourcade and Chatelain 1998; Zwergel et al, 1998). Cases were collected between March 1997 and June 1998. Follow-up data were available for all patients. At the time of the present study, all patients were alive. Average age was 57 years at the time of diagnosis.

Three of ten of the low-grade tumors were found, unexpectedly, in sovrapubic enucleation (latent or incidental carcinomas). The remaining seven cases of low-grade tumor and all cases of high-grade tumor came from cases involving radical prostatectomies after a diagnosis on a transurethral resection specimen. For each patient, $6 \mathrm{~mm}$-thick samples were taken from both the tumoral area and the contralateral normal and/or benign hyperplastic area. Each sample was divided into two parts, one part was used for biochemical analysis and the other was formalin-fixed and paraffin-embedded for conventional histopathology and immunohistochemical assessment of Pyk2 expression. A section stained with hematoxylin and eosin (H\&E) from each specimen was examined to confirm the original diagnosis.

\section{Pathology and Immunohistochemistry}

For each paraffin-embedded sample, $4 \mu \mathrm{m}$-thick serial sections were mounted on slides pretreated for immunohistochemistry. The sections were deparaffinized in xylene and rehydrated through graded ethanols to deionized distilled water and incubated in a $750 \mathrm{~W}$ microwave oven for 15 minutes in $10 \mathrm{~mm}$ buffered citrate, $6.0 \mathrm{pH}$, to complete antigen unmasking (Shi et al, 1991). The avidin-biotin peroxidase complex method was used to visualize the reaction products (Hsu et al, 1981).

Endogenous peroxidases were quenched by incubation in $0.1 \%$ sodium azide with $0.3 \%$ hydrogen peroxide for 30 minutes at room temperature. Nonspecific binding was blocked by incubation with nonimmune serum (1\% Tris-bovine albumin for $15 \mathrm{~min}$ utes at room temperature).

Sections were incubated overnight with anti-Pyk2 at a 1:200 dilution or with anti-pp125 Fak at a dilution of 1:100. Normal rabbit serum was substituted for the primary antibody as a negative control. The standard avidin-biotin peroxidase complex (ABC) procedure was performed, and the peroxidase activity was developed with a filtered solution of $5 \mathrm{mg}$ of 3-3'diaminobenzideine tetrahydrochloride (dissolved in 10 $\mathrm{ml}$ of $0.05 \mathrm{M}$ Tris buffer, $\mathrm{pH} 7.6$ ) and $0.03 \% \mathrm{H}_{2} \mathrm{O}_{2}$. Mayer's hematoxylin was used to counter-stain the nuclei. Sections were mounted with a synthetic medium.

Immunohistochemistry was evaluated independently by two observers, each blind to the original histologic diagnosis and to the follow-up data of the 
single cases. For each case, eight to ten high-power fields from representative areas of the tumor and, respectively, from normal and/or hyperplastic prostate were examined. Cells with a brown precipitate in the cytoplasm were graded as immunoreactive for the Pyk2 protein. Cells exhibiting a weak, irregularly distributed cytoplasmic precipitate were graded as negative. The proportion of Pyk2 positive cells was ranked on a semiquantitative scale, as I (negative, $0 \%$ to $5 \%$ of cells were immunoreactive), II (5\% to $25 \%$ of cells were immunoreactive), or III (more than $25 \%$ of cells were immunoreactive). Fak expression was expressed as only immunoreactive or not.

\section{Antibodies}

Antibodies against Pyk2 (\#600 and \#638) and P-Tyr (\#72) were previously described (Dikic et al, 1998). Pyk2 antibodies were raised in rabbits immunized with GST fusion proteins containing amino acids 362 to 647 of Pyk2 or against a synthetic peptide corresponding to a 15 amino acid N-terminal residue (Lev et al, 1995). Affinity-purified polyclonal (06-543) and monoclonal (05-182) antibodies against pp125 FAK were purchased from Upstate Biotechnology, Lake Placid, New York.

\section{Cell Culture}

PC3 and PC12 cell lines were obtained from the American Type Culture Collection (Rockville, Maryland). PC12 cells were maintained in RPMI 1640 (Gibco BRL, Paisley, Scotland) with 5\% FCS and $0.5 \%$ horse serum. PC3 cells were maintained in DMEM (Gibco BRL) with 10\% FCS and 100 units $/ \mathrm{ml}$ of penicillin, (Sigma Chemical, Poole, Dorset, United Kingdom) and $0.1 \mathrm{mg} / \mathrm{ml}$ of streptomycin (Sigma) at $37^{\circ} \mathrm{C}$ and $5 \% \mathrm{CO}_{2}$.

\section{Immunoprecipitation and Western Blot Analysis}

For immunoprecipitation, $10^{6}$ to $10^{7}$ cells were washed twice in ice-cold PBS $(0.2 \mathrm{~g} / \mathrm{l}$ of $\mathrm{KCl}, 0.2 \mathrm{~g} / \mathrm{l}$ of $\mathrm{KH}_{2} \mathrm{PO}_{4}, 8 \mathrm{~g} / \mathrm{l}$ of $\mathrm{NaCl}$, and $2.16 \mathrm{~g} / \mathrm{l}$ of $\left.\mathrm{Na}_{2} \mathrm{HPO}_{4}\right)$ and lysed in lysis buffer (50 mM HEPES, $150 \mathrm{~mm} \mathrm{NaCl,} 1$ mM EDTA, 1 mм EGTA, 10\% glycerol, 1\% Triton $\mathrm{X}-100,1 \mathrm{~mm}$ phenylmethylsulfonyl fluoride, $1 \mu \mathrm{g}$ of aprotinin, $0.5 \mathrm{~mm}$ sodium orthovanadate, and $20 \mathrm{~mm}$ sodium pyrophosphate). The lysates were clarified by centrifugation at $14,000 \times \mathrm{g}$ for 10 minutes. Frozen human samples were homogenized directly into lysis buffer. Protein concentrations were estimated by a Bio-Rad assay (Bio-Rad, München, Germany). Fifty microliters of protein A-Sepharose (Amersham Pharmacia Biotech, Buckinghamshire, England) were incubated with $5 \mu$ l of rabbit anti-Pyk2 for 1 hour at $4^{\circ} \mathrm{C}$, and incubated with equal amounts of total protein lysates for 2 hours at $4^{\circ} \mathrm{C}$. Immunoprecipitates were washed four times with HNTG (20 mm Hepes, 15 mm $\mathrm{NaCl}, 0.1 \%$ Triton $\mathrm{X}-100$, and $5 \%$ or $10 \%$ glycerol) and boiled in Laemmli buffer $(0.125 \mathrm{~m}$ Tris- $\mathrm{HCl} \mathrm{pH} 6.8$, $4 \%$ SDS, 20\% glycerol, 10\% 2-mercaptoethanol, $0.002 \%$ bromophenol blue) for 5 minutes before electrophoresis (Tokiwa et al, 1996). Immunoprecipitates were subjected to SDS-PAGE (7.5\% polyacrylamide) under reducing conditions. After electrophoresis, proteins were transferred to nitrocellulose membranes (Immobilon Millipore Corporation, Bedford, Massachusetts). Complete transfer was assessed using prestained protein standards (Bio-Rad, Hercules, California). After blocking with TBS-BSA (TBS with 5\% bovine serum albumin), the membrane was incubated with the primary antibody to phosphotyrosine (1:400), Pyk2 (1:500), or Fak (1 mg/ml of protein) in TBS-BSA for 1 hour at room temperature. All of the primary antibodies used were rabbit polyclonal IgGs raised against the peptide sequences. Membranes were incubated with horseradish peroxidase-conjugated secondary antibodies (1:2000) for 45 minutes at room temperature, and reactions were detected with the ECL system (Amersham Life Science, UK).

\section{Statistical Analysis}

Statistical analysis was performed by the KruskalWallis test (ANOVA for non-parametric data), corrected by Dunn's post-test.

\section{Acknowledgements}

We would like to thank Dr. Domenico Fulgione and Mr. Bruno Teocle for skillful technical assistance in the artwork.

\section{References}

Balbay M D, Pettaway CA, Kuniyasu H, Inoue K, Ramirez E, Li E, Fidler IJ, and Dinney CP (1999). Highly metastatic human prostate cancer growing within the prostate of athymic mice overexpresses vascular endothelial growth factor. Clin Cancer Res 5:783-789.

Berthon P, Waller AS, Villette JM, Loridon L, Cussenot O, and Maitland NJ (1997). Androgens are not a direct requirement for the proliferation of human prostatic epithelium in vitro. Int J Cancer 73:910-916.

Bostwick DG, Grignon DJ, Hammond ME, Amin MB, Cohen M, Crawford D, Gospadarowicz M, Kaplan RS, Miller DS, Montironi R, Pajak TF, Pollak A, Srigley JR, and Yarbro JW (2000). Prognostic factors in prostate cancer. Arch Pathol Lab Med 124:995-1000.

Bruyninx M, Ammar H, Reiter E, Cornet A, and Closset J (2000). Genes upregulated during castration-induced rat prostatic apoptosis: Cloning and characterization of new cDNAs. BJU Int 85:1134-1142.

Chauhan D, Hideshima T, Pandey P, Treon S, Teoh G, Raje $\mathrm{N}$, Rosen S, Krett N, Husson H, Avraham S, Kharbanda S, and Anderson KC (1999). RAFT/PYK2-dependent and -independent apoptosis in multiple myeloma cells. Ocogene 18:6733-6740.

Craft N, Shostak Y, Carey M, and Sawyers CL (1999). A mechanism for hormone independent prostate cancer through modulation of androgen receptor signaling by the Her-2/Neu tyrosine kinase. Nat Med 5:280-285.

Culing Z, Hobisch A, Cronauer MV, Hittmair A, Radmayr C, Bartsch G, and Klocker H (1995). Activation of the androgen receptor by polypeptide growth factors and cellular regulators. World J Urol 13:285-289. 
Culing Z, Hobisch A, Cronauer MV, Radmayr C, Hittmair A, Zhang J, Thurnher M, Bartsch G, and Klocker H (1996). Regulation of prostatic growth and function by peptide growth factors. Prostate 28:393-405,

Dikic I, Dikic I, and Schelssinger J (1998). Identification of a new Pyk2 isoform implicated in chemokine and antigen receptor signaling. J Biol Chem 273:14301-14308.

Dikic I, Tokiwa G, Lev S, Courtneidge SA, and Schlessinger J (1996). A role for Pyk2 and Src in linking G-protein-coupled receptors with Map kinase activation. Nature 383:547-550.

Felsch JS, Lane WS, and Peralta EG (1999). Tyrosine kinase Pyk2 mediates G-protein-coupled receptor regulation of the Ewing sarcoma RNA-binding protein EWS. Curr Biol 9:485-488.

Fourcade RO and Chatelain C (1998). Androgen deprivation for prostatic carcinoma: A rationale for choosing components. Int J Urol 5:303-311.

Ganju RK, Dutt P, Wu L, Newman W, Avraham H, Avraham S, and Groupman JE (1998a). Beta-chemokine receptor CCR5 signals via the novel tyrosine kinase RFTK. Blood 91:791-797.

Ganju RK, Munshi N, Nair BC, Liu ZY, Gill P, and Groupman $J(1998 b)$. Human immunodeficiency virus tat modulates the Flk-1/KDR receptor mitogen-activated protein kinases, and components of focal adhesion in Kaposi's sarcoma cells. J Virol 72:6131-6137.

Gioeli D, Mandell JW, Petroni GR, Frierson HF Jr, and Weber MJ (1999). Activation of mitogen-activated protein kinase associated with prostate cancer progression. Cancer Res 59:279-284.

Gleason DF and Mellinger GT (1974). The Veterans Administration Cooperative Urological Research Group: Prediction of prognosis for prostatic adenocarcinoma by combined hystological grading and clinical staging. J Urol 111:58-64.

Gleason DF (1977). The Veterans Administration Cooperative Urological Research Group: Hystological grading and clinical staging of prostatic carcinoma. In: Tannenbaum M, editor. Urologic pathology, the prostate. Philadelphia: Lea \& Febiger, 171-197.

Griffiths K, Cockett ATK, Coffey D, Krieg M, Lee C, McKeehan W, Neal DE, Partin A, Di Santagnese AP, and Schalken J (1997). Regulation of prostatic growth. In: Griffiths K and Denis LJ editors. Fourth International Consultation on BPH. FCI Paris. Cardiff, UK: Compgraphics Service, 83-129.

Guo C, Zheng C, Martin-Padura I, Bian ZC, and Guan JL (1998). Differential stimulation of proline-rich tyrosine kinase 2 and mitogen-activated protein kinase by sphingosine 1-phosphate. Eur J Biochem 257:403-408.

Hatch WC, Ganju RK, Hiregowdara D, Avraham S, and Groupman JE (1998). The related adhesion focal tyrosine kinase (RFTK) is tyrosine phosphorylated and participates in colony-stimulating factor-1/macrophage colony stimulating factor signaling in monocyte-macrophage. Blood 91:39673973.

Hsu SM, Raine L, and Fanger H (1981). Use of Avidin-Biotinperoxidase complex (ABC) immunoperoxidase techniques: $A$ comparison between $A B C$ and unlabelled antibody (PAP) procedures. J Histochem Cytochem 29:577-580.

Humphrey PA, Frazier HA, Vollmer RT, and Paulson DF (1993). Stratification of pathologic features radical prostatectomy specimens that are predictive of elevated initial postoperative serum prostate-specific antigen levels. Cancer $71: 1821-1827$
Inazawa J, Sasaki H, Nagura K, Kakazu N, Abe T, and Sasaki T (1996). Precise localization of the human gene encoding cell adhesion kinase b (CAK b/PYK2) to chromosome 8 at p21.1 by $\beta$ in situ hybridization. Hum Genet 98:508-510.

Kalapurakal JA, Jacob AN, Kim PY, Najjar DD, Hsieh YC, Ginsberg P, Daskal I, Asbell SO, and Kandpal RP (1999). Racial differences in prostate cancer related to loss of heterozygosity on chromosome 8p12-23. Int J Radiat Oncol Biol Phys 45:835-840.

Konig JJ, Teubel W, van Steenbrugge GJ, Romijn JC, and Hagemeijer A (1999). Characterization of chromosome 8 aberrations in the prostate cancer cell line LNCaP-FGC and sublines. Urol Res 27:3-8.

Lee C, Kozlowsky JM, and Greyhack JT (1997). Intrinsic and extrinsic factors controlling benign prostatic growth. Prostate 31:131-138.

Lev S, Moreno H, Martinez R, Canoll P, Peles E, Musacchio JM, Plowman GD, Rudy B, and Schlessinger J (1995). Protein tyrosine kinase Pyk2 involved in $\mathrm{Ca}^{2+}$-induced regulation of ion channel and MAP kinase function. Nature 376:737-744.

Lin MF, Meng TC, Rao PS, Chang C, Schonthal AH, and Lin FF (1998). Expression of human prostatic acid phosphatase correlates with androgen-stimulated cell proliferation in prostate cancer cell lines. J Biol Chem 273:5939-5947.

Liu ZY, Ganju RK, Wang JF, Ona MA, Hatch WC, Zheng T, Avraham S, Gill P, and Groupman JE (1997). Cytokine signaling through the novel tyrosine kinase RAFTK in Kaposi's sarcoma cells. J Clin Invest 99:1798-1804.

Mazzucchelli L, Loetscher P, Kappeler A, Uguccioni M, Baggiolini M, Laissue JA, and Mueller C (1996). Monocyte chemoattractant protein-1 gene expression in prostatic hyperplasia and prostate adenocarcinoma. Am J Pathol 149:501-509.

Moore BB, Areberg DA, Stoy K, Morgan T, Addison SB, Glass M, Wilke C, Xue JJ, Sitterding S, Kunkel SL, Burdick MD, and Strieter RM (1999). Distinct CXC chemokines mediate tumorigenicity of prostate cancer cells. Am J Pathol 154:1503-1512.

Moul JW (1999). Angiogenesis, p53, bcl-2 and Ki-67 in the progression of prostate cancer after radical prostatectomy. Eur Urol 35:399-407.

Mukhopadhyay D, Nagy JA, Manseau EJ, and Dvorak HF (1998). Vascular permeability factor/vascular endothelial growth factor-mediated signaling in mouse mesentery vascular endothelium. Cancer Res 58:1278-1284.

Owens LV, Xu L, Craven RJ, Dent GA, Weiner TM, Kornberg L, Liu ET, and Cance WG (1995). Overexpression of the focal adhesion kinase $\left(\mathrm{p} 125^{\mathrm{FAK}}\right)$ in invasive human tumors. Cancer Res 55:2752-2755.

Pandey P, Avraham S, Place A, Kumar V, Majumder PK, Cheng K, Nakazawa A, Saxena S, and Kharbanda S (1999a). $\mathrm{Bcl}-\mathrm{xL}$ blocks activation of related adhesion focal tyrosine kinase/proline-rich tyrosine kinase 2 and stress-activated protein kinase/c-Jun $\mathrm{N}$-terminal protein kinase in the cellular response to methylmethane sulfonate. J Biol Chem 274: 8618-8623.

Pandey P, Avraham S, Kumar S, Nakazawa A, Place A, Ghanem L, Rana A, Kumar V, Majumder PK, Avraham H, Davis RJ, and Kharbanda S (1999b). Activation of p38 mitogen-activated protein kinase by PYK2: Related adhesion focal tyrosine kinase-dependent mechanism. J Biol Chem 3:115-126. 
Reinikainen P, Palvino JJ, and Janne OA (1996). Effects of mitogens on androgen receptors-mediated transactivation. Endocrinology 137:4351-4357.

Robinson D, Feng H, Pretlow T, and Hsing-Jien KA (1996). Tyrosine kinase profile of prostate carcinoma. Proc Natl Acad Sci USA 93:5958-5962.

Ruijter E, Van De Kaa C, Miller G, Ruiter D, Debruyne F, and Schalken J (1999). Molecular genetics and epidemiology of prostate carcinoma. Endocr Rev 20:22-45.

Russell PJ, Bennett S, and Stricker P (1998). Growth factor involvement in progression of prostate cancer. Clin Chem 44:705-723.

Sasaki H, Nagura K, Ishino M, Tobioka H, Kotani K, and Sasaki T (1995). Cloning and characterization of celladhesion kinase beta, a novel protein-tyrosine kinase of the focal adhesion kinase subfamily. J Biol Chem 270:2120621219.

Schaller MD, Borgman CA, Cobb BN, Vines RR, Reynolds $A B$, and Parsons JT (1992). pp125 ${ }^{\text {AAK }}$ a structurally distinctive protein-tyrosine kinase associated with focal adhesion. Proc Natl Acad Sci USA 89:5192-5196.

Sherwood ER, Van Dongen JL, Wood CG, Liao S, Kozlowski JM, and Lee C (1998). Epidermal growth factor receptor activation in androgen-independent but not androgenstimulated stimulated growth of human prostatic carcinoma cells. Br J Cancer 77:855-861.

Shi SR, Key ME, and Karla K (1991). Antigen retrieval in formalin-fixed, paraffin-embedded tissues: An enhancement method for immunohistochemical staining based on microwave oven heating of tissue section. J Histochem Cytochem 39:741-748.

Sieg DJ, llic D, Jones KC, Damsky CH, Hunter T, and Schlaepfer DD (1998). Pyk2 and Src-family protein-tyrosine kinases compensate for the loss of FAK in fibronectinstimulated signaling events but Pyk2 does not fully function to enhance FAK-cell migration. EMBO J 17:5933-5947.

Susa M (1999). Heterotrimeric G proteins as fluoride targets in bone. Int J Mol Med 3:115-126.

Talpin ME, Bubley GJ, Shuster TD, Frantz ME, Spooner AE, Ogata GK, Keer HN, and Balk SP (1995). Mutation of the androgen-receptor gene in metastatic androgenindependent prostate cancer. N Engl J Med 332:1393-1398.

Tokiwa G, Dikic I, Lev S, and Schlessinger J (1996). Activation of Pyk2 by stress signals and coupling with JNK signaling pathway. Science 273:792-794.

Tremblay L, Hauck W, Aprikian AG, Begin LR, Chapdelaine A, and Chevalier S (1996a). Focal adhesion kinase (pp125Fak) expression, activation and association with paxillin and p50CSK in human metastatic prostate carcinoma. Int $\mathrm{J}$ Cancer 68:164-171.
Tremblay L, Hauck W, Nguyen LT, Allard P, Landry F, Chapdelaine A, and Chevalier S (1996b). Regulation and activation of focal adhesion kinase and paxillin during the adhesion, proliferation, and differentiation of prostatic epithelial cells in vitro and in vivo. Mol Endocrinol 10:1010-1020.

Udayakumar TS, Jeyaraj DA, Rajalakshmi M, and Sharma RS (1999). Culture of prostate epithelial cells of the rhesus monkey on extracellular matrix substrate: Influence of steroids and insulin-like growth factors. J Endocrinol 162:443450.

Ueda H, Abbi S, Zheng C, and Guan JL (2000). Suppression of Pyk2 kinase and cellular activities by FIP200. J Cell Biol 149:423-430.

Van Alewijk DC, Van der Weiden MM, Eussen BJ, Van Den Andel-Thijssen LD, Ehren-van Eekelen CC, Konig JJ, van Steenbrugge GJ, Dinjens WN, and Trapman J (1999). Identification of a homozygous deletion at 8p12-21 in a human prostate cancer xenograft. Genes Chromosomes Cancer 24:119-126.

Veltri RW, Miller MC, Zhao G, Ng A, Marley GM, Wright GL Jr, Vessella RL, and Ralph D (1999). Interlukin-8 serum levels in patients with benign prostatic hyperplasia and prostate cancer. Urology 53:139-147.

Visakorpi T, Hyytinen E, Koivisto P, Tanner M, Keinanen R, Palmberg C, Palotie A, Tammela T, Isola J, and Kallioniemi OP (1995). In vivo amplification of the androgen receptor gene and progression of human prostate cancer. Nat Genet 9:401-406.

Visakorpi T (1999). New pieces to the prostate cancer puzzle. Nat Med 5:264-265.

Xie W, Wong YC, and Tsao SW (2000). Correlation of increased apoptosis and proliferation with development of prostatic intraepithelial neoplasia (PIN) in ventral prostate of the Noble rat. Prostate 15:31-39.

Xiong W and Parson JT (1997). Induction of apoptosis after expression of Pyk2, a tyrosine kinase structurally related to focal adhesion kinase. J Cell Biol 139:529-539.

Zheng C, Xing Z, Bian ZC, Guo C, Akbay A, Warner L, and Guan J (1998). Differential regulation of Pyk2 and focal adhesion kinase (FAK). J Biol Chem 273:2384-2389.

Zwergel T, Kakirman H, Rohde V, Wullich B, and Unteregger $G$ (1998). Androgen receptor expression, proliferation index and aneuploidy in tissue explant cultures derived prostate carcinoma cells co-cultivated on membranes. Eur Urol 33: 414-423. 